Finisterra, XXXVII, 73, 2002, pp. 33-59

\title{
O AMBIENTE NAS POLÍTICAS PÚBLICAS EM PORTUGAL ${ }^{1}$
}

MARgARIDA QueIRós ${ }^{2}$

\begin{abstract}
Resumo - Apesar dos cerca de trinta anos de acções em matéria ambiental, é apenas em meados dos anos 80, pela perspectiva de adesão ao espaço comunitário, que se definem e afirmam as linhas programáticas de actuação ambiental nacional, consolidadas ao longo da década de 90. Acompanhando a tendência europeia, a política ambiental portuguesa avançou em direcção a uma acção preventiva, pelo menos em alguns domínios. Com efeito, o país atravessou um período de reflexão e definição de prioridades ambientais em praticamente todas as áreas da vida económica e social. Traduzindo o esforço financeiro público (administração central e local), as orientações estratégicas da política ambiental enfatizaram iniciativas que exigiram pesados investimentos em infra-estruturas.

Neste artigo mostram-se os desenvolvimentos da política ambiental do Estado português, traduzidos pelo suporte financeiro atribuído no Orçamento de Estado (em concreto, na Conta Geral do Estado) a projectos ambientais que se desenrolam de acordo com uma lógica sectorial e territorial. Este percurso é abordado em complementaridade com a evolução da orgânica interna da administração central e respectiva organização de serviços públicos vocacionados para os problemas do ambiente e afins. Neste particular aspecto, a análise evolutiva da orgânica dos serviços de ambiente e a sua tutela evidencia a importância relativa crescente do ambiente no seio das políticas públicas.
\end{abstract}

Palavras-chave: política pública de ambiente, instituições e serviços de ambiente, despesas e investimentos de desenvolvimento.

\begin{abstract}
Environmental Public Policies In Portugal - Despite almost thirty years of environmental activities with the first 'environmental' steps taken in Portugal in the early 1970s, it was only in the mid-1980s with Portugal's joining the European Community that policy guidelines for environmental action were drawn up and established and later consolidated in the 1990s. In accordance with the general European trend, the Portuguese environmental policy was aimed at preventive measures, at least in some areas. Portugal reflected on the issues over a period of time and defined environmental priorities in practically all areas of economic and social life. In terms of the state's financial projects (central and local
\end{abstract}

1 Este artigo baseia-se na investigação desenvolvida pela autora relativa à dissertação de doutoramento. Cf. QueIrós (2001).

2 Investigadora do Centro de Estudos Geográficos e Prof. ${ }^{a}$ Auxiliar da Faculdade de Letras, Universidade de Lisboa. E-mail: margaridaq@mail.doc.fl.ul.pt 
administration), strategy for environmental policies put the emphasis on undertakings that required heavy investment in infrastructures.

This article describes the development of the government's environmental policy in Portugal as reflected in the financial support given to environmental projects, according to industrial or geographical criteria, from the state budget. This process is addressed along with the development of the central administration and respective organisation of public services that handle environmental problems and such like. In this aspect, examination of the development of the environmental services structure and its concomitant duties demonstrates the importance given to environmental issues in public policies.

Key words : environmental public policies, environmental institutions and services, development expenditure and investment.

\section{INTRODUÇÃO}

O esforço de despesa pública que contribui para colmatar as carências do país nos domínios do ambiente é indicativo das orientações de política do sector. Através de um conjunto de projectos, a política de ambiente tem objectivos a atingir e essa tarefa é tanto mais visível quanto se avaliam as necessidades, em termos de investimentos, para o cumprimento das directivas comunitárias e normas internas respeitantes ao ambiente. Esta exigência envolve frequentemente critérios de decisão que procuram os benefícios ambientais e o bem-estar social mas é penalizada pela diversidade dos domínios ambientais, que englobam, entre outras acções, a construção de infra-estruturas, iniciativas de conservação do património natural e actividades de investigação e de sensibilização que, por sua vez, envolvem uma pluralidade de actores (autarquias, administração central, empresas industriais e de serviços, centros de investigação, etc.).

Sabe-se que os custos associados às necessidades nacionais em matéria de ambiente são elevados, dada a "quase ausência» histórica de uma sólida política e uma cultura ambiental pouco desenvolvida, assim como a diversidade das condicionantes sócio-políticas que o país atravessou. A entrada em vigor dos Quadros Comunitários de Apoio obrigou, no entanto, a trabalhos de avaliação de investimentos e alargou as perspectivas nacionais em relação à capacidade financeira para efectuar despesas ambientais, circunstância que multiplicou as fontes de financiamento (as dotações comunitárias, a respectiva contrapartida nacional, o investimento nacional não co-financiado, etc.).

Nos últimos anos, a rápida evolução das questões ambientais - conceitos, problemas e soluções - conduziu, naturalmente, a transformações do próprio quadro institucional (MARN, 1994). Essas transformações dizem respeito às estruturas dos organismos da administração central. Ademais, estes constituem um núcleo principal de qualquer sistema institucional porque, naturalmente, elegem as condições básicas para o exercício de competências legítimas nos domínios do ambiente face à Constituição de 1976; exprimem ainda a cons- 
ciência dos custos económicos da degradação do ambiente e a sua influência nas estratégias de política e, por isso, determinada concepção de desenvolvimento sustentável.

Existe um grau de incerteza quanto aos volumes exactos de financiamento, porquanto múltiplas entidades desempenham uma função de liderança nos financiamentos públicos: União Europeia, administração central/Ministério do Ambiente (e outros ministérios), administração local/autarquias, entre outros organismos. Aliás, alguns dos documentos disponíveis da contabilidade pública nacional nem sempre são claros na separação entre o investimento exclusivamente nacional e o co-financiado. Assim, as ordens de grandeza aqui analisadas foram encaradas, sempre que possível, em termos relativos face aos valores das verbas globais.

Afigura-se importante sublinhar que os domínios ambientais considerados neste artigo ultrapassam os estritamente tutelados pelo Ministério do Ambiente, tendo-se procurado completar a análise daqueles com a associação de informação de outros departamentos da administração central que possuem programas de investimento no sector ambiental. Procura-se ainda dar a conhecer a natureza, o tipo e a dimensão dos projectos/acções de defesa do ambiente e sua implantação territorial apoiados pela administração central e com expressão a nível local, indicativos também eles de um determinado enquadramento conceptual que se pretende apontar. Por este motivo, tendo competências bem delimitadas para a realização de investimentos públicos em domínios ambientais (saneamento básico, água, ar, ruído...) ${ }^{3}$, o papel da administração local não podia deixar de ser aqui referido.

\section{A ESTRUTURA ORGÂNICA DO «SUBSECTOR» ESTADO 4 PARA A POLÍTICA DE AMBIENTE}

O Orçamento do Estado (OE) é um dos instrumentos de política económica mais importantes de um país, na medida em que representa a intenção anual de despesa do sector público. A Conta Geral do Estado (CGE) é, todavia, o instrumento mais correcto para analisar as orientações, despesas e investimentos do Estado, porquanto traduz as contas executadas face ao previsto no Orçamento do Estado ${ }^{5}$. Talvez mais importante do que os gastos em ambiente, registados na

3 O DL 77/84, de 8 de Março, estabelece o regime de delimitação e coordenação das actuações da administração central e local em matéria de investimentos públicos.

4 O Sector Público Administrativo é constituído pelo Subsector Estado, Fundos e Serviços Autónomos, Administrações Regionais e Locais e Segurança Social.

5 A base da investigação é realizada com o recurso às Contas do Estado que já disponibilizam as despesas consolidadas referentes a dois anos anteriores à data da publicação do Orçamento de Estado de um determinado ano. A utilização do OE amplificaria os financiamentos; veja-se, por exemplo, que em 1995 o OE previa uma despesa total do Ministério do Ambiente que só foi efectuada em $81,3 \%$, valor que baixa para $76,1 \%$ no ano seguinte. 
CGE, serão os serviços do Estado criados para a sua gestão e respectivos projectos ou domínios de intervenção, também eles inscritos na CGE. A estrutura orgânica definida para a execução da política de ambiente expõe os pilares e os objectivos do governo (ordenamento do território, educação ambiental...); o conjunto de acções é revelador do tipo de política que se pretende implementar (salvaguarda do meio natural, alteração da capacidade de intervenção da população, etc.).

A apreciação da actuação do Estado inicia-se em 1970, data em que se dão os primeiros passos para a consolidação da política de ambiente em Portugal, e termina no penúltimo orçamento do século Xx. A abordagem adoptada, para conhecer os domínios ambientais e a sua distribuição por serviços administrativos, é construída segundo a componente orgânica (por ministérios) do «Subsector» Estado.

Uma observação atenta do percurso do ambiente no período seleccionado revela que a formalização da política pública de ambiente foi, por um lado, gradualmente implementada por várias tutelas, que vão desde o Ministério do Equipamento Social e do Ambiente (MESA), o Ministério da Habitação e Obras Públicas (MHOP), o Ministério da Qualidade de Vida (MQV) ao Ministério do Planeamento e da Administração do Território (MPAT) e, como tal, segundo lógicas de protecção ambiental «hesitantes» ou intervenções pouco claras ou ainda ajustadas ao perfil executivo da tutela no qual, salvo as devidas excepções, ocuparam um lugar marginal. Por outro lado, se bem que, durante o período de existência do MQV, a política de ambiente se procurasse associar à do ordenamento do território, quando aquele organismo se dissolve o "ambiente» é integrado no MPAT, separado do ordenamento do território e sujeito às imposições dos serviços de obras públicas, em geral, e de hidráulica, em particular.

Estas opções permitiram a atomização dos domínios ambientais por diversos serviços administrativos pertencentes a vários ministérios e, mesmo aquando da institucionalização do Ministério do Ambiente e dos Recursos Naturais (MARN), que deveria polarizar e coordenar horizontalmente a política de ambiente dos outros ministérios, reconhecem-se dificuldades de intervenção dadas as suas competências limitadas, sobretudo ao nível do ordenamento do território.

Dentro destas restrições, pretende-se sintetizar, em primeiro lugar, os caminhos da política de ambiente levada a cabo pelo Estado português nas suas diversas formulações institucionais ligadas ao sector público administrativo, desde o «reconhecimento de uma esfera ambiental no interior das missões do Estado» (SOROMENHO-MARQuES, 1994: 112), seguido da sua integração no elenco ministerial durante os Governos Provisórios, passando pelos sucessivos Governos Constitucionais até aos finais dos anos 90. Procuram-se, depois, interpretar as orientações de financiamento em ambiente de acordo com a classificação orgânica apresentada nas Contas do Estado (e esta observação foi efectuada transversalmente, isto é, para todos os ministérios) por forma a compreender o processo de elaboração da própria consciência política ambiental ao nível sectorial. A metodologia utilizada reflecte então uma pesquisa em todos os ministérios e 
serviços que de alguma maneira estiveram na base dos actuais departamentos governamentais orientados para as questões do ambiente. Assim, a estrutura do Ministério do Ambiente dos anos 90 serviu de orientação para guiar a investigação da actividade dos serviços ligados ao ambiente no passado.

\section{Os primeiros passos}

A primeira estrutura do Estado dedicada às questóes do ambiente foi uma comissão permanente de estudos, designada por Comissão Nacional do Ambiente (CNA), dependente da Junta Nacional de Investigação Científica e Tecnológica (JNICT) e criada, em 1971, por Marcello Caetano (AnTas, 1987; Melo e Pimenta, 1993; Dga, 1994; Soromenho-Marques, 1994; Ribeiro Telles, 1995; Correia DA CunHA, 1999). O seu aparecimento está relacionado com a preparação portuguesa para a Conferência das Nações Unidas sobre o Ambiente Humano de $1972 \mathrm{em}$ Estocolmo ${ }^{6}$. Por forma a fazer progredir os preparativos para a Conferência, a Comissão Económica das Nações Unidas para a Europa agenda uma reunião em 1971 em Praga (conhecida por Simpósio de Praga), na qual Portugal participa com A Monografia Nacional sobre os Problemas Relativos ao Ambiente. Este é o primeiro documento oficial que aponta os problemas ambientais que afectam o país (Evangelista, 1992; IPAMB, 1999).

O Programa de Acção da CNA, preparado já nos finais de 1971 e incluído no respectivo Relatório de Actividades, pretende traduzir as linhas gerais da política nacional de ambiente e equaciona a inevitabilidade do seu aparecimento na preparação e execução do IV Plano de Fomento ${ }^{7}$ (CORREIA DA CUNHA, 1999). No âmbito deste documento as principais acções directas a desenvolver no âmbito nacional seriam: i) luta contra a poluição; ii) melhoria do ambiente urbano; iii) defesa dos meios rurais e iv) protecção dos recursos naturais. Estas acções iriam ser complementadas com medidas indirectas, tais como a promoção de estudos, campanhas de informação, criação de estruturas administrativas adequadas, etc. (CORREIA DA CUNHA, 1999).

Com a CNA surgem as primeiras realizações públicas e trabalhos de investigação dedicados ao estado do ambiente em Portugal (no relatório de 1972, a CNA propõe a constituição de um grupo de trabalho para o estabelecimento de um Atlas Nacional do Ambiente). Desta entidade nascem os primeiros corpos técnicos especializados que vêm a viabilizar a operacionalização dos futuros serviços públicos do ambiente (Melo e Pimenta, 1993).

Se bem que a CNA tivesse sido criada para a participação de Portugal na Conferência de Estocolmo, as condições para que a política de ambiente

6 Na sequência de uma nota do Secretário Geral das Nações Unidas em 1969, enviada ao Ministério dos Negócios Estrangeiros e que transmitia uma resolução da Assembleia Geral das Nações Unidas no sentido de convocar uma conferência mundial sobre o ambiente.

7 A partir da década de 1950, a política de desenvolvimento económico global do país foi alvo de programações a médio prazo, definidas através dos Planos de Fomento. 
pudesse ser concebida e executada de uma forma coordenada eram mínimas (IPAMB, 1999). Os ministérios das Obras Públicas e Economia, durante o período que antecedeu o 25 de Abril de 1974, eram os principais responsáveis pelas áreas afins do ambiente. A administração pública estava então vocacionada para os domínios da economia e da engenharia que privilegiaram, numa lógica sectorial, os grandes investimentos públicos como forma de estímulo ao crescimento económico.

Atravessava-se um período de crescimento económico rápido apesar de Portugal ser um dos países mais pobres da Europa Ocidental. Para Silva LopeS (1996), a política orçamental dos governos de todo o período do Estado Novo era dominada pelo objectivo de evitar défices orçamentais à custa do sacrifício de despesas essenciais com a educação, saúde e segurança social, efectuando apenas investimentos, ainda que controlados, nas infra-estruturas económicas.

Como é óbvio, uma política ancorada em grandes projectos públicos, debaixo de um forte dirigismo económico, não deixou muito espaço para as preocupações ambientais. Tendo em conta os estímulos externos para o aprofundamento da investigação em domínios ambientais, alguns progressos foram feitos ao nível nacional, em concreto, no que respeita aos recursos hídricos. Com efeito, em 1965, a UNESCO lançou o Decénio Hidrológico Internacional com o objectivo de procurar uma avaliação dos recursos hídricos mundiais e de promover o desenvolvimento da hidrologia, cujo programa em Portugal visava a recolha e análise de dados de base, sua interpretação e promoção de investigação naquele domínio (VEIGA DA CunHa et al., 1974).

As intervenções realizadas ou previstas de grande envergadura com interferência no ambiente (acções concentradas de desenvolvimento) são características desta época. Destacam-se as áreas valorizadas por importantes empreendimentos produtores de energia hidroeléctrica e pelo armazenamento de água para os grandes perímetros de rega, no sentido de incentivar o crescimento e modernização da agricultura (CORREIA DA CUNHA, 2000). As principais referências vão para os aproveitamentos hidráulicos da Cova da Beira e Campina da Idanha, do Alentejo (Plano de Rega do Alentejo), do Mondego e o alargamento do regadio pelo aproveitamento da rede hidrográfica do Algarve (PRESIDÊNCIA Do CONSELHO, 1974).

Relacionadas com a aceleração do processo de desenvolvimento económico, as preocupações com a degradação do ambiente surgem muito claramente no IV Plano de Fomento (PRESIDÊNCIA Do ConselHo, 1974). Um conjunto de medidas genéricas de matriz pública eram então equacionadas para que, no decurso daquele Plano, fossem objecto de maior atenção: preservação do ambiente e protecção da Natureza, luta contra a poluição (ar, ruído, águas interiores e mares) e protecção e melhoria dos ambientes rural e urbano. Determinados problemas ambientais no continente foram enunciados e eram já apontadas, como zonas prioritárias de actuação na protecção do ambiente, as áreas urbanizadas de Lisboa e Porto, as áreas rurais do interior e outras mais desenvolvidas e, ainda, toda a orla marítima costeira (incluindo os estuários do Tejo e 
do Sado). O IV Plano de Fomento previa que a política de protecção do ambiente fosse promovida, orientada e coordenada pela CNA, depois de devidamente reorganizada. As directrizes de uma tal política orientar-se-iam para os domínios do saneamento básico e da saúde. Todavia, com o 25 de Abril de 1974, este Plano não chegaria a concretizar-se.

Em 1974, com o I Governo Provisório, é criado o Ministério do Equipamento Social e Ambiente (MESA). A criação deste ministério resulta do desmembramento dos ministérios da Economia (cuja mega-estrutura englobava a agricultura, a silvicultura e a indústria) e das Obras Públicas. É também instituído o cargo de Subsecretário de Estado do Ambiente, dependente do MESA, de início com poderes quase nulos mas lentamente ganhando competências. A CNA é integrada no MESA e tornada dependente do Subsecretário de Estado do Ambiente. Nesta altura, o MESA tem um peso de $24,4 \%$ do total de despesas do Estado, o que foi verdadeiramente inédito.

Durante os I a V Governos Provisórios, sobretudo no período de 1974 e 1975, as actividades produtivas entraram em crise em resultado do primeiro choque petrolífero, da descolonização e das perturbações do período revolucionário (SILVA LOPES, 1996). As tarefas que dominaram os primeiros tempos após a mudança do regime político centraram-se na gestão da transformação da estrutura produtiva e da política social. A designação dos organismos ministeriais (ministérios do Equipamento Social e do Ambiente e dos Assuntos Sociais) e respectivas dotações orçamentais reflectem a crescente preocupação com a situação social e uma orientação política orientada para a melhoria da qualidade de vida da população.

Acrescente-se ainda que as recém-constituídas estruturas de ambiente procuravam (se bem que na maior parte dos casos infrutiferamente) disciplinar a expansão urbana e a construção de infra-estruturas, como forma de contrabalançar os efeitos do crescimento. Neste contexto surge, ainda em 1975, a Secretaria de Estado do Ambiente (SEA), «directamente ligada ao Primeiro Ministro» (Ribeiro Telles, 1995: 73), procurando estabelecer uma interligação dos problemas do ambiente com os do ordenamento do território.

A criação da SEA evidencia um momento alto na história da política ambiental portuguesa. No novo contexto, as acções ambientais, no seu essencial, centram-se no apoio à investigação. E consagram a política da conservação da Natureza através da criação, em 1975, do Serviço Nacional de Parques, Reservas e Património Paisagístico (SNPRPP). Muito embora não se registe uma preocupação pluridisciplinar explícita, um aspecto de assinalar é o facto dos vários ministérios terem preocupações relacionadas com domínios ambientais afins das suas áreas directas de intervenção. Esta estrutura «híbrida» dos ministérios só desaparecerá a partir de 1990, com a criação do Ministério do Ambiente.

Não se pode ignorar que o período 1976-78 é atravessado por vários governos, os quais procuraram conceder prioridade ao combate à crise iniciada em 1973 e promover a recuperação da economia portuguesa. Nos finais dos anos 
70, estava em causa uma balança de transacções com saldo negativo e uma imposição de cortes orçamentais com base num programa de recuperação económica, pelo que o lugar de uma política ambiental era substancialmente menos importante (SILVA LoPES, 1996).

Ao constituir-se o II Governo Constitucional, em 1978, a SEA, sob nova designação (Secretaria de Estado do Ordenamento Físico e Ambiente, SEOFA), transita para a tutela do Ministério da Habitação e Obras Públicas (MHOP). Ainda em 1978 (já no III Governo Constitucional), os Recursos Hídricos e Aproveitamentos Hidráulicos ficam integrados na SEOFA e, mais uma vez, as questões ambientais se submetem a projectos de engenharia hidráulica (DGQA, 1990). Na sua maioria liderados por engenheiros, os serviços do MHOP privilegiam a construção, consolidação e reparação de obras hidráulicas (saneamento básico e aproveitamentos hídricos) e assim reduzem a política de ambiente aos grandes projectos públicos ou, como afirma Ribeiro Telles (1995: 75), «à política do betão».

A estrutura orgânica do MHOP reflecte um conjunto alargado de acções levadas à prática na área da construção de obras hidráulicas e de saneamento básico. Aliás, é de assinalar a criação da Direcção-Geral de Saneamento Básico (DGSB) que se propunha assegurar a política de saneamento básico, bem como promover e enquadrar os estudos regionais de planeamento do sector (SIMÕES, 1985). No que se refere ao domínio da conservação da Natureza e recuperação de paisagens (orientado para os "estudos»), o MHOP opta por desenvolver diagnósticos da situação ambiental. Observa-se ainda que, nesta altura, o Ministério da Agricultura e Pescas desempenha um papel igualmente importante em acções de defesa da Natureza, talvez complementar do MHOP.

Um outro aspecto que merece atenção relaciona-se com a procura de energias alternativas (inclusive a opção pela energia nuclear) que se começa a observar desde o orçamento de 1975 no Ministério da Economia. Sendo o contexto internacional desfavorável, em resultado do choque petrolífero de 1973, é um sinal das preocupações dos sucessivos governos pelos efeitos negativos na economia interna e consciência da fragilidade do sector energético nacional. Merece ainda uma referência o financiamento do projecto hidroagrícola do Alqueva, associado ao Ministério das Finanças e do Plano em 1978, reflectindo, como afirmam Melo e Pimenta (1993), uma política centrada em projectos megalómanos típicos da teoria, então em voga, dos pólos de crescimento.

Em 1980, a SEOFA fica sob a tutela do Primeiro Ministro; no resto a orgânica do Governo não é diferente dos anos 1976-77. Após várias denominações e figurinos de acordo com os sucessivos governos, em 1981 (VII Governo Constitucional) é criado o Ministério da Qualidade de Vida (MQV) que integra a SEOFA (DGQA, 1990). O MQV, entre outros domínios, passa a tutelar a qualidade do ambiente, os desportos, o ordenamento e a defesa do consumidor, articulando e integrando um conjunto de competências que afectam o ambiente. É neste período que nasce a Direcção-Geral da Qualidade do Ambiente (DGQA), inicialmente dotada de competência para incentivar o desenvolvimento de tecnologias de carácter pouco poluente. 
Multiplicam-se os estudos e projectos interdisciplinares, reflectindo sobretudo a associação do ambiente ao ordenamento do território. Porque juntou o ordenamento ao ambiente, ao mesmo tempo que lhes atribuiu estrita conexão com a protecção dos consumidores e o desporto/recreação, o MQV tornou-se um marco histórico nas preocupações ambientais do Estado (RIBEIRo TELLES, 1995). A nova divisão das áreas de intervenção, patente através do Ministério da Qualidade de Vida e do Ministério do Equipamento Social, Obras Públicas, Habitação e Urbanismo (ex-MHOP), espelha as competências de organização do espaço e utilização racional dos recursos naturais e construídos, como competências do MQV; ao ex-MHOP cabe a gestão dos recursos hídricos.

A primeira metade dos anos 1980 foi difícil para as actividades económicas em Portugal (Silva Lopes, 1996), pelo que, apesar do significado da criação do MQV para o desenvolvimento da política de ambiente, o seu orçamento modesto revela que o restabelecimento das contas externas foi prioritário nas opções do Governo.

Convém referir que, na época, diversas competências dos domínios do ambiente (ou com actuações susceptíveis de provocar impactes ambientais) ainda se encontram claramente dispersas por outros ministérios. Refira-se o alargamento do controlo da poluição hídrica levado a cabo pelo Ministério dos Assuntos Sociais através do apetrechamento em equipamento laboratorial, a acção do Ministério das Finanças e do Plano no apoio a grandes projectos infra-estruturantes (como o Alqueva) e a intervenção do Ministério da Agricultura, se bem que agora mais focalizada no sector florestal, relacionada com o Projecto Florestal Português, apoiado financeiramente pelo Banco Mundial, que entrou em vigor em 1980 (DAVEAU, 1991). O Ministério da Administração Interna passa ainda a ter competências nas intervenções físicas relacionadas com a infra-estruturação dos aglomerados populacionais de âmbito local e regional.

Em 1985, a SEOFA é rebaptizada (Secretaria de Estado do Ambiente e dos Recursos Naturais, SEARN) e integrada no recém criado Ministério do Plano e Administração do Território e é extinto o MQV (Evangelista, 1992; Melo E PIMENTA, 1993). A SEARN duplica o seu orçamento e finalmente alarga a esfera de actuação para a gestão dos recursos hídricos e controlo de áreas protegidas (Melo e Pimenta, 1993). No entanto, as obras hidráulicas e de saneamento continuam a absorver grande parte do orçamento do MPAT. Note-se que só a partir de 1988 as antigas e poderosas Direcções-Gerais dos Recursos e Aproveitamentos Hidráulicos e do Saneamento Básico, pertencentes ambas ao antigo Ministério das Obras Públicas e depois tuteladas pelo MPAT, são extintas e o que resta delas é incorporado na Direcção-Geral dos Recursos Naturais (DGRN). Acrescente-se que, em 1986, já o MPAT integrava a DGQA, para a qual haviam também passado algumas das competências das Direcções-Gerais dos Recursos e Aproveitamentos Hidráulicos e do Saneamento Básico.

Para Ribeiro Telles (1995), a separação do ambiente e do ordenamento com a destituição do MQV e a consequente integração da SEARN no MPAT significou um «rude golpe para a política de ambiente» que se vinha construindo. No 
entanto, apesar da falta de visão ambiental dos serviços hidráulicos, foi de extrema importância a intervenção da SEARN na gestão de áreas protegidas e no controlo da poluição. Acresce uma mudança de situação, em 1986, quando se estrutura organicamente o Serviço Nacional de Parques Reservas e Conservação da Natureza (SNPRCN) que, segundo EvANGELISTA (1992), apresentava problemas decorrentes da própria dispersão espacial dos parques e reservas e das diferenças internas de conceitos no enunciado das finalidades do novo serviço. Entre 1985-89 observa-se uma "centralização» da política ambiental no MPAT, que se fez acompanhar de uma multiplicação específica de áreas de intervenção ambiental.

Pode assim dizer-se que a integração e reestruturação dos serviços do ambiente no MPAT introduz alterações significativas no percurso da política de ambiente desenvolvida pelo extinto MQV. As transformações orgânicas de 1985 representam um salto qualitativo na política de ambiente em Portugal - este é talvez um sinal da preparação para as exigências da adesão à Comunidade Europeia que se avizinhavam. Em 1985, os serviços dedicados ao ambiente eram apenas o Instituto e o Gabinete da Defesa do Consumidor, o Gabinete do Secretário de Estado do Ambiente e a Direcção-Geral da Qualidade do Ambiente. Porém, de 1986 a 1989, a orgânica do MPAT amplia-se. Nesta perspectiva verifica-se, tal como entende SoROMENHO-MARQUES (1998: 86), que é apenas a partir de 1986 que se assiste a "uma aceleração dos mecanismos tendentes a permitir uma mais ágil política de ambiente». É preciso esclarecer que nestes mecanismos se incluem os financiamentos decorrentes da integração do ambiente no Acto Único Europeu em 1987 e da reafirmação dos princípios da solidariedade, que levam a Comissão a ampliar consideravelmente os seus fundos com finalidade estrutural. Apesar do incremento, a despesa executada pelo MPAT em domínios ambientais representa apenas uma pequena parte do Orçamento do Estado (em 1989, a Conta Geral do Estado apresentava um total de 2.728,8 milhões de contos em despesas executadas em todos os ministérios; ao MPAT cabiam 143,7 milhões de contos, dos quais apenas 11,7 são atribuíveis a gastos com rubricas ambientais).

A partir de 1985, a economia portuguesa entra numa fase de transformações substanciais: a entrada na Comunidade Europeia em 1986 e a estabilidade governativa desde 1987 foram os principais factores da melhoria das condições de vida (SILVA LOPES, 1996). As transformações estruturais que ocorreram durante o período 1985-90 implicaram a expansão da produção e um aumento do consumo privado ao mesmo tempo que os problemas ambientais se complexificaram. Note-se o alargamento da esfera de acção da DGQA (passa a incorporar as funções das extintas DGARH e DGSB), a sua orientação preferencial para a inventariação do estado do ambiente em Portugal e, simultaneamente, o esforço de organização dos mecanismos de combate à poluição (organização de informação ambiental, uma área pouco explorada até então).

Não se pode esquecer que a segunda metade da década de 80 ficou associada ao início do sistema legislativo na área da qualidade do ambiente, como o 
demonstra o enquadramento da política ambiental emanado da Lei de Bases do Ambiente, publicada em 1987. Também a Lei das Associações de Defesa do Ambiente, no mesmo ano, é um marco no processo de institucionalização da política de ambiente: as associações de defesa do ambiente são a forma mais explícita da sociedade mostrar o estímulo colectivo na procura da qualidade ambiental. De acordo com Melo e Pimenta (1993: 151), desde os finais dos anos 80, «o ambiente tornou-se institucional e socialmente respeitável» em Portugal.

\section{Os anos 90 do século $\mathrm{XX}$}

Em 1990, a SEARN dá lugar ao Ministério do Ambiente e dos Recursos Naturais (MARN) ${ }^{8}$, órgão governamental dotado de maior capacidade de intervenção. Dos serviços deste novo ministério, transitando do MPAT, a DGQA torna-se um serviço central operacional, assim como a Direcção-Geral dos Recursos Naturais (DGRN) e o Instituto Nacional de Defesa do Consumidor (INDC) passam também a depender do MARN. À então DGQA $^{9}$ cabiam as funções de promoção, estudo e colaboração nas acções susceptíveis de contribuir para o equilíbrio e estabilidade ambientais. Passam para o referido serviço as competências da Direcção de Serviços do Controlo e Poluição, da Direcção-Geral de Recursos e Aproveitamentos Hidráulicos e do Centro Tecnológico e Divisão de Documentação e Informação da Direcção-Geral de Saneamento Básico (DGQA, 1990). A DGQA associava vários serviços (qualidade da água; qualidade do ar e do ruído; de resíduos e compostos químicos; de poluição industrial; centro de investigação do ambiente e centro de documentação) e a sua estrutura orgânica caracterizava-se por uma forte componente vertical.

No decurso das várias reestruturações do Ministério da tutela, a sua sucessora, a DGA, vai desintegrando serviços, alguns deles depois reestruturados e dependentes do Secretário de Estado Adjunto do Ministro do Ambiente (por exemplo, o Instituto de Resíduos). Porém, a DGA mantém funções de coordenação das iniciativas da política de ambiente (avaliação de impacte ambiental, certificação, actividade laboratorial, etc.) e é o elo de ligação nacional à Agência Europeia do Ambiente. Dependentes deste Ministério que tutela o ambiente, estão também os serviços desconcentrados das Direcções Regionais do Ambiente (Norte, Centro, Lisboa e Vale do Tejo, Alentejo e Algarve).

Logo após a sua criação dão-se alterações na orgânica do MA que ocorrem entre 1993 e 1997. Surgem sob a sua tutela, mas como entidades dotadas de

8 O MARN foi criado com o DL 94/90, de 20 de Março, e a respectiva lei orgânica consta do DL 294/91, de 13 de Agosto. Abreviado em 1995 para Ministério do Ambiente (MA), designação que será usada daqui em diante, muito embora este departamento do Estado tenha sido entretanto designado Ministério do Ambiente e do Ordenamento do Território (MAOT) e actualmente Ministério das Cidades, Ordenamento do Território e Ambiente (MCOTA).

9 Até 1993, depois passa a designar-se Direcção Geral do Ambiente (DGA) e, actualmente, Instituto do Ambiente (IA). 
autonomia administrativa, diversos institutos: o Instituto Regulador das Águas e Resíduos e os Institutos da Água, dos Resíduos, da Navegabilidade do Douro, de Meteorologia, de Promoção Ambiental e da Conservação da Natureza (MA/SGDRH, 1998).

Em 1999, em resultado da remodelação orgânica do Governo, o MA assumiu novamente as competências do ordenamento do território, passando a designar-se Ministério do Ambiente e do Ordenamento do Território (MAOT) - e já na década de 2000 é reestruturado, passando a Ministério das Cidades, Ordenamento do Território e Ambiente (MCOTA). Sendo cedo para julgar a eficácia desta complexa união, aquele foi decididamente um passo decisivo na tão desejada (re)aproximação da defesa dos recursos naturais ao ordenamento do território.

As prioridades políticas no que respeita ao ambiente não se esgotam na orgânica do Ministério da tutela; outros departamentos governamentais com domínios afins desempenham um papel assinalável nesta matéria, muito embora a sua sensibilidade para o actual objectivo do desenvolvimento sustentável seja muito discutível. Se bem que a criação de um ministério que tutela os domínios do ambiente reflicta o reforço da intervenção qualificada do Estado, o verdadeiro desafio da coordenação da política de ambiente nas outras políticas públicas é em Portugal uma conquista ainda não completamente alcançada.

\section{O ESFORÇO FINANCEIRO PÚBLICO PARA O AMBIENTE}

Após a reflexão acerca da orgânica administrativa para os assuntos do ambiente, procede-se à análise do respectivo esforço financeiro, decorrente da responsabilidade do Governo e coordenado pela administração central ${ }^{10}$. Naturalmente, é desejável que se analise também a contribuição da administração local para a valorização e protecção ambiental dos seus territórios. De facto, no quadro das suas atribuições e competências, as autarquias desempenham um papel de extrema importância na gestão ambiental, pelo que a evolução do investimento municipal neste domínio não podia deixar de ser referida ${ }^{11}$.

$\mathrm{Na}$ figura 1 comparam-se as despesas da administração central e local na gestão e protecção do ambiente no Continente. É notória a preponderância da

10 Esta análise termina em 1997, pois a «consolidação do OGE» (a execução em relação à orçamentação) é realizada pelo Ministério das Finanças até final dos exercícios seguintes, devendo depois ser remetida ao Tribunal de Contas até ser submetida à AR. Só com o esforço dos últimos anos se conseguiu a aprovação da CGE até 1997 porque durante longos anos o documento não era alvo de qualquer apreciação.

11 A principal fonte utilizada é a série estatística do INE publicada nas Estatísticas do Ambiente que têm uma periodicidade anual a partir de 1993, muito embora neste ano se apresentem conjuntamente as séries dos anos 1989-92. Assim, a série temporal que se obtém inicia-se em 1989 e termina em 1997, data da última publicação disponível das Estatísticas do Ambiente. 
despesa dos municípios face às instituições da administração central. Se bem que a legislação confira às autarquias responsabilidades no atendimento público em diversos domínios ambientais, na verdade, em finais da década de 80 , os montantes para este fim eram modestos (cerca de 40 milhões de contos). Em ambas as administrações, o panorama evolui logo no início da década de 90.

Como se observa pelo envolvimento activo nas despesas e investimentos em domínios da gestão e protecção ambiental, as autarquias locais são protagonistas da política do ambiente (em 1997, as despesas das autarquias rondavam os 100 milhões de contos, enquanto as da administração central eram quase metade). Com efeito, o quadro de competências autárquicas em matéria de ambiente, os seus poderes na determinação da localização de actividades condicionantes do ordenamento do território, a fiscalização e os compromissos com

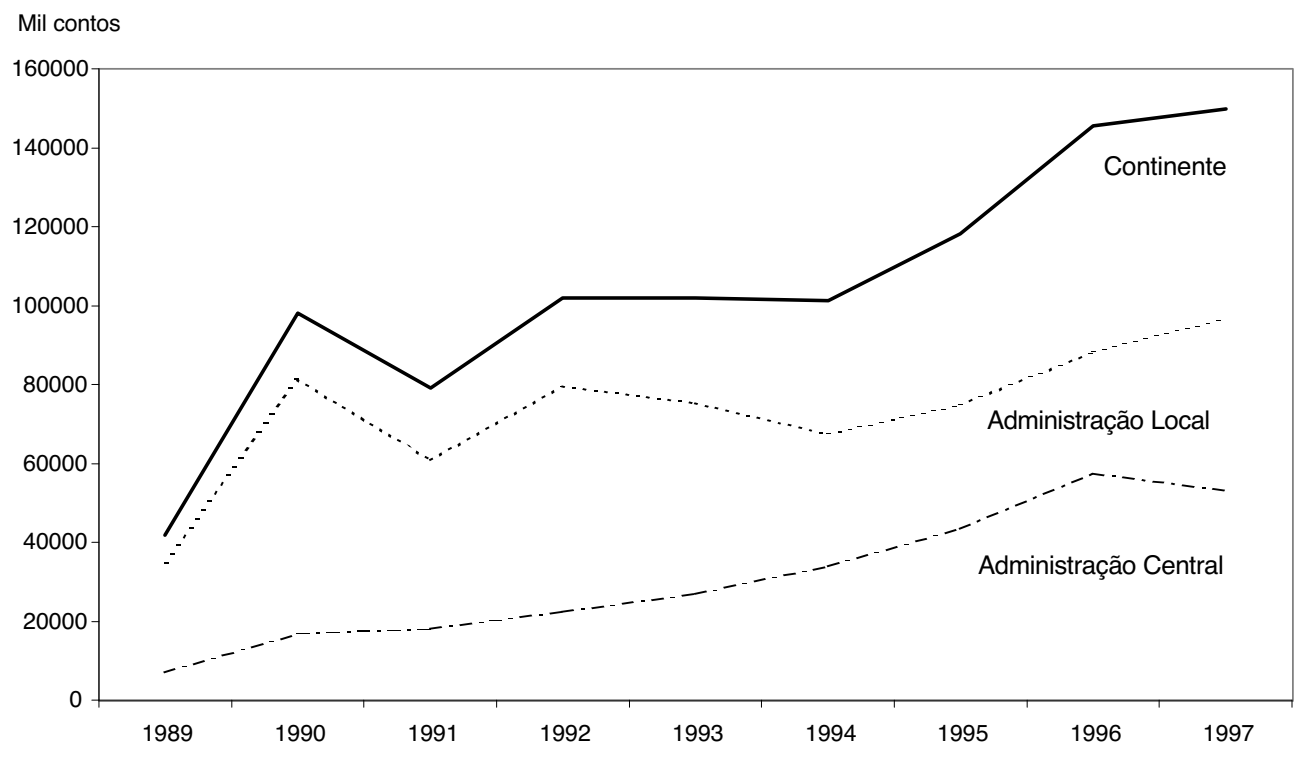

INE, Estatísticas do Ambiente, 1989-97

Fig. 1 - Despesas das administrações públicas central e local em ambiente, 1989-97.

Fig. 1 - Expenditure of central and local administration on environmental protection, 1989-97.

os munícipes, conferem-lhe responsabilidades no fornecimento de água, no tratamento de águas residuais domésticas, recolha de resíduos, conservação dos espaços verdes, etc. (CORREIA, 1995).

Será no entanto conveniente lembrar que este enquadramento é devedor da atitude da administração central, dado que sob a sua responsabilidade se 
assumiu serem relevantes muitos dos problemas ambientais à escala local, optando por utilizar o sector empresarial do Estado e o Fundo de Coesão como incentivos ao seu maior envolvimento. Os financiamentos provenientes da UE permitiram a recuperação de parte do atraso estrutural dos municípios em matéria de ambiente. Naturalmente, é preciso recordar que nem todas as Câmaras Municipais possuem capacidade técnica e financeira para executar as mudanças no capítulo do ambiente, pelo que a cooperação intermunicipal, ou mesmo com a administração central, se revela uma solução adequada.

Apesar do ritmo crescente dos investimentos públicos em ambiente na década de 90, a publicação Environmental Protection Expenditure in Member States 1988-96 (Eurostat, 1999) mostra que, em 1995, Portugal gastou 624 milhões de ECU, o que equivale apenas a $0,8 \%$ do PIB nacional em despesas na protecção ambiental (correspondendo a 63 ECU per capita contra $186 \mathrm{ECU}$ per capita no mesmo ano para a UE). Ainda em 1995, a mesma fonte estatística revela que o total da UE gasto em ambiente corresponde a 1,0\% do PIB comunitário. Apesar de representar uma pequena parte da riqueza gerada na UE dos 15, a despesa relativa em ambiente tem crescido. Com efeito, entre 1992-95, a despesa total em ambiente da UE em \% do PIB aumentou 13\%, e a despesa da UE per capita sofreu um incremento de $36 \%$.

\section{Dos gastos públicos do Estado na última década do século $\mathbf{X X}$}

Ao longo dos cerca de trinta anos estudados, a evolução anual dos financiamentos do sector do ambiente foi positiva, se bem que irregular, mostrando que as prioridades ambientais foram variando de acordo com os diversos ciclos da economia portuguesa.

No que respeita à execução das despesas do ministério da tutela em relação à execução orçamental da CGE, pode verificar-se que, em termos líquidos, a dotação financeira do MA, entre 1990 e 1997, mais que duplica (15,9 para 33,4 milhões de contos, a preços correntes); todavia, este aumento foi ligeiramente inferior ao aumento do orçamento geral do país no mesmo período (3.437,9 para 7.548,8 milhões de contos, a preços correntes).

Quando associada ao percurso vacilante das entidades responsáveis pelo ambiente que, desde a Secretaria de Estado ao Ministério do Ambiente, «vaguearam» por vários ministérios, vem confirmar a ideia de que, apesar do estímulo da UE, a política pública neste domínio tornou-se tão prioritária como qualquer das outras áreas de intervenção e, para alguns, considerada como não «estrategicamente direccionada» face às restantes políticas do país (SoromenHo-MARQUES, 1998: 89).

A figura 2 mostra que o MA em Portugal, se bem que com um orçamento crescente, não foi alvo de discriminação positiva nas preocupações do Governo. De facto, em termos relativos, o orçamento do MA tem vindo a seguir uma trajectória ligeiramente descendente nas despesas globais do Estado - nos anos em análise, situa-se entre os 0,4\% e os 0,6\% da Conta Geral do Estado. Esta 


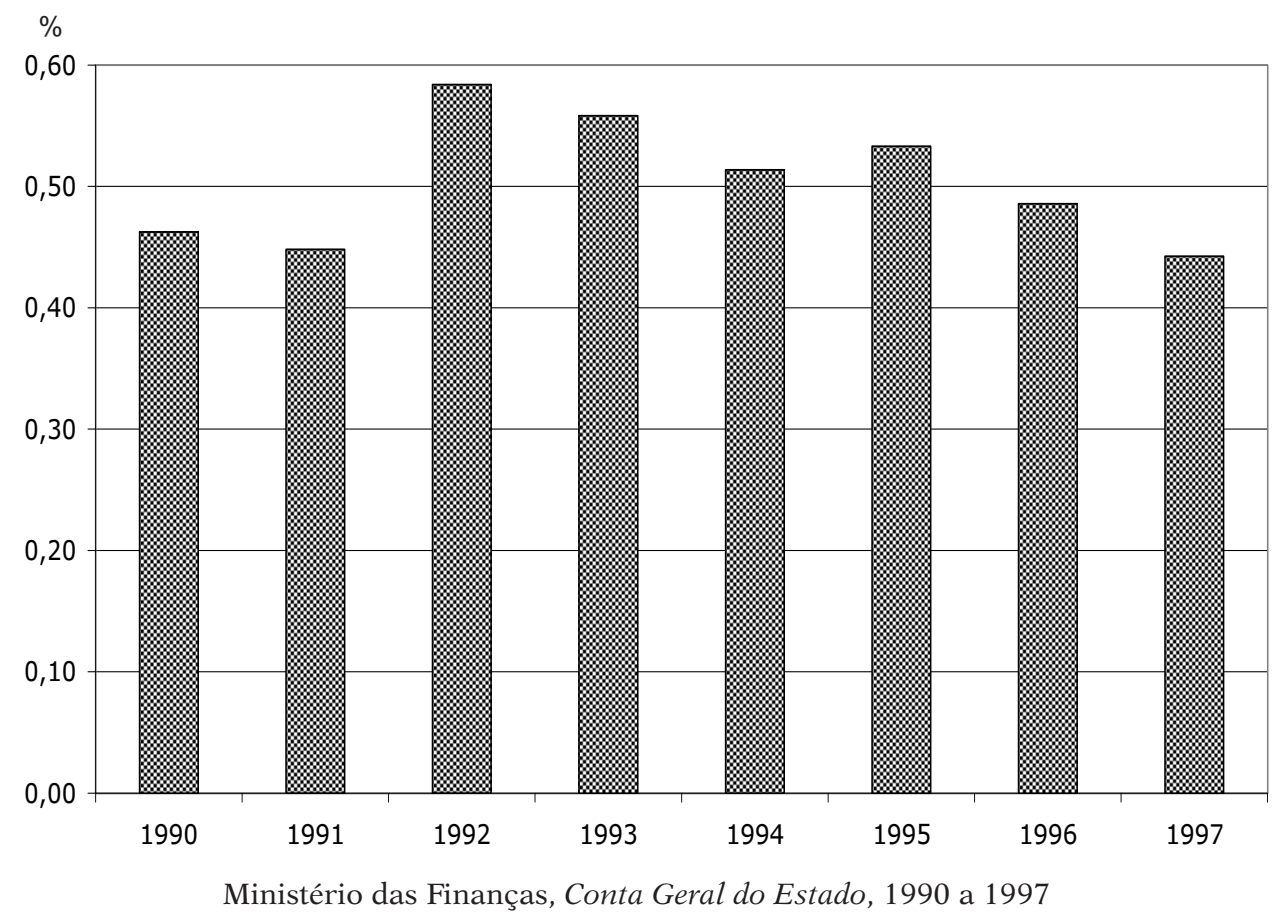

Fig. 2 - Evolução do peso do orçamento do MA na Conta Geral do Estado, 1990-1997.

Fig. 2 -Trends in the Environment Department budget in the State budget, 1990-1997.

situação não é de todo estranha: as medidas de protecção e recuperação ambiental são muito dispendiosas e Portugal é um país de fracos recursos económicos. Se o Estado português teve como alavanca estruturante a integração na Comunidade e como tal viu reforçada a sua política de ambiente, quando se observa o orçamento da UE percebe-se que as verbas consignadas para o ambiente são também comedidas.

No período 1990-97, a observação das «transferências» constantes nas CGE para instituições públicas e privadas que operam nos domínios ambientais, na execução orçamental do MA, mostra, por um lado, que são particularmente notórias as diligências para apoiar projectos externos de formação e investigação no domínio do ambiente, desenvolvidos em particular por instituições universitárias e institutos de investigação públicos.

Para a década de 90, salientam-se, ainda nas CGE, os elevados montantes financeiros direccionados para os Serviços e Fundos Autónomos do MA (os seus financiamentos resultam quer de transferências do Ministério quer de receitas próprias): o Instituto da Conservação da Natureza (ex-SNPRCN, depois ICN) e a Direcção-Geral do Recursos Naturais (DGRN, que virá a dar lugar ao Instituto da Água, INAG). 
De um modo geral, pode dizer-se que, durante o período em análise, as CGE no que se refere às despesas e investimentos do MA reflectem uma intervenção continuada nos recursos hídricos (sobretudo estratégias de protecção, conservação e gestão integrada das águas superficiais, subterrâneas e costeiras, de reabilitação e construção de infra-estruturas hidráulicas e de reconversão e modernização das redes de saneamento básico); porém, as acções de defesa do ambiente, de valorização do património natural, de definição e conservação de áreas protegidas e as acções de monitorização da qualidade do ambiente revelam, pouco a pouco, que o MA tem assumido um compromisso sério com a valorização da paisagem.

\section{O investimento e desenvolvimento em ambiente induzido pelo Estado português}

Após a delimitação das principais estruturas institucionais que executam a política de ambiente, respectivos domínios de actuação e gastos públicos, procura-se de seguida destacar os investimentos do Estado em ambiente e, na medida do possível, numa óptica espacializada.

Para além das despesas (ordinárias ou correntes), faz também parte do esforço financeiro do Estado o "Capítulo 50 do OE» correspondente a uma importante componente do Plano de Investimentos e Despesas de Desenvolvimento da Administração Central (PIDDAC). O Capítulo 50 do Orçamento de Estado (OE) é uma rubrica financeira presente na CGE, especialmente consignada aos investimentos do Estado. Só é possível conhecer com rigor as fontes de financiamento do Capítulo 50 a partir de 1994. Até então, podem estar contemplados no Capítulo 50 do OE parte do financiamento comunitário, bem como financiamentos provenientes de outras fontes (Serviços e Fundos Autónomos, Empresas Públicas, etc.). Neste ponto, serão analisadas as despesas financiadas através do Capítulo 50 do OE que, segundo o Departamento de Prospectiva e Planeamento (DPP, 1996 e 1998), é a principal fonte de financiamento nacional do PIDDAC ${ }^{12}$.

Na figura 3 esquematizam-se as fontes de financiamento do PIDDAC, para evidenciar a sua estrutura de financiamento. Como se pode observar, o PIDDAC conta com financiamentos directos do Capítulo 50 do OE, mas também de outras fontes nacionais. Conta, ainda, com os financiamentos da União Europeia, através dos Fundos Comunitários. Segundo o DPP (1998), a maior parte do

12 O PIDDAC é o instrumento de coordenação das intervenções a cargo dos vários órgãos da administração central (DPP, 1996 e 1998) e tem como objectivo assegurar o investimento do Estado aprovado anualmente pela Assembleia da República, no âmbito das Grandes Opções do Plano (GOP). Com efeito, o PIDDAC é ele próprio um mapa aprovado pela AR (Mapa XI do OE). As grandes opções indicam as prioridades da política do governo que se concretizam através da actividade legislativa e das despesas constantes do Capítulo 50 do OE, também conhecido por Investimentos do Plano. 


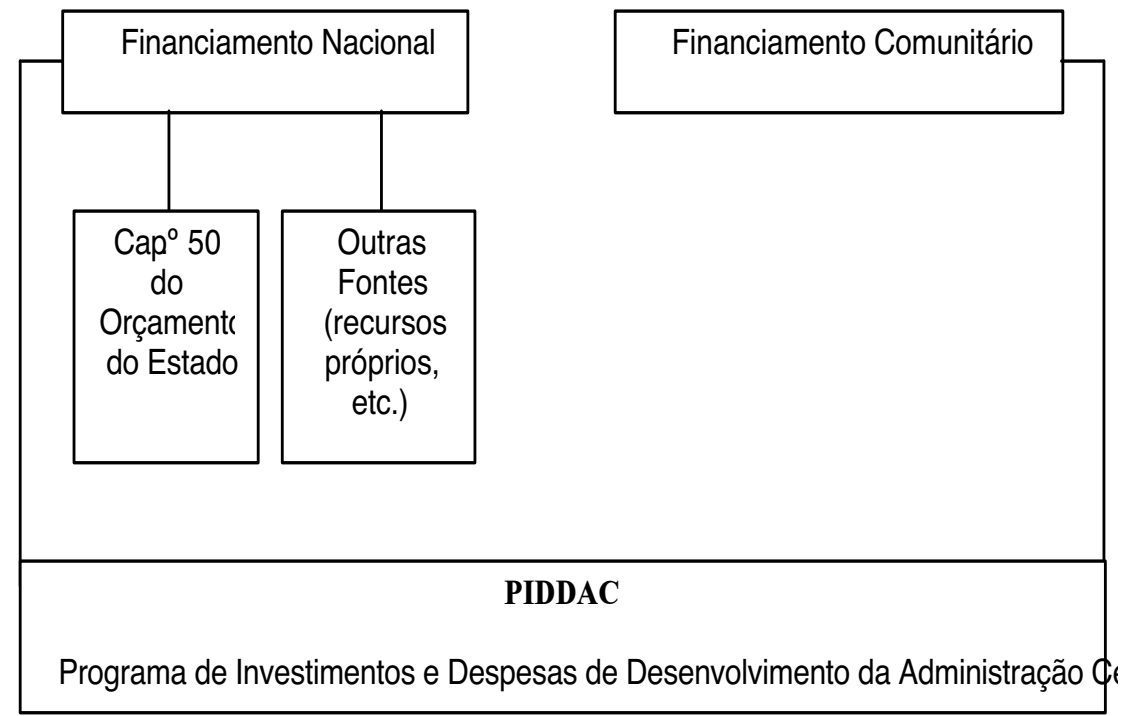

Fig. 3 - As fontes de financiamento do PIDDAC.

Fig. 3-Financial sources of the investments and development budget of the Central Administration (PIDDAC).

financiamento comunitário é incluído nas Outras Fontes do PIDDAC mas também se incorpora no Capítulo 50 do OE. Na construção do PIDDAC, é fundamental o financiamento público comunitário, habitualmente inferior à comparticipação pública nacional (do total de despesa realizada, em média o financiamento nacional é de cerca de $60 \%$ contra $30 \%$ relativo ao comunitário) (DPP, 1998).

É precisamente através da discriminação do tipo/áreas de investimento que se pode apreender como se estruturam as prioridades do Estado, materializadas em projectos de desenvolvimento com impacte territorial. No que se refere à incidência geográfica dos seus projectos, a espacialização do PIDDAC é elaborada tendo por base as indicações inscritas no Mapa XI do OE. Segundo o DPP, a tradução espacial dos investimentos da administração central defronta-se com a dificuldade em afectar inequivocamente o investimento a nível concelhio. Este problema decorre da natureza do investimento de alguns sectores, nomeadamente, a investigação científica, sistemas de incentivo e outros apoios ao investimento, aumentando proporcionalmente a importância do investimento multiregional. Esta questão é particularmente sensível no que respeita aos domínios do ambiente.

A figura 4 traduz a execução financeira do Capítulo 50 do OE para o período de 1989-98, com especial destaque para os investimentos em ambiente. Devido a limitações próprias da organização do PIDDAC, para o período que 
decorre entre 1989 a 1993, o DPP não separa as suas fontes de financiamento, pelo que as verbas encontradas podem incluir simultaneamente financiamentos nacionais e comunitários. A correcta separação das fontes de financiamento na elaboração do PIDDAC é apenas efectuada a partir de 1994. A partir de então é visível o esforço do Estado português no investimento ambiental (os montantes expressos na figura 4 referem-se exclusivamente ao financiamento nacional efectuado através do Capítulo 50 do OE).

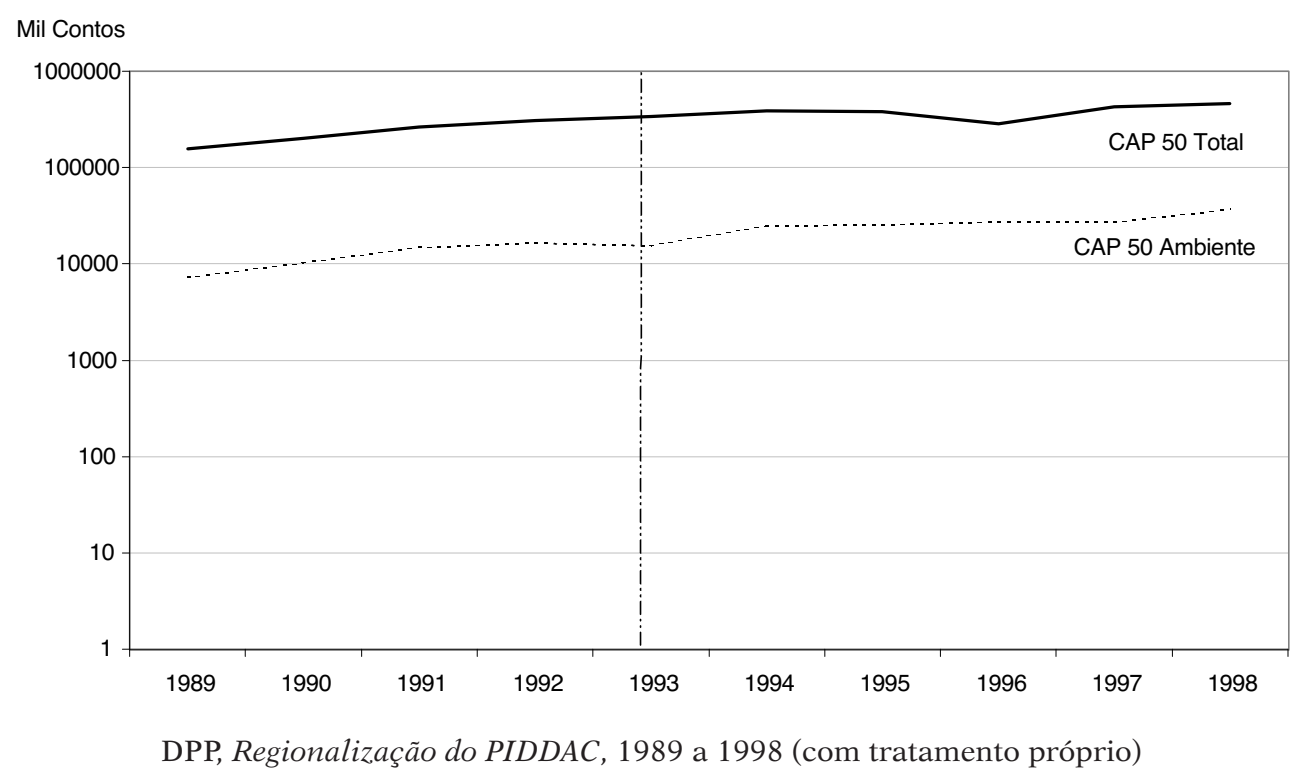

Fig. 4 - Evolução do Cap. 50 OE-Ambiente e do Cap. 50 OE-total para o Continente, 1989-98.

Fig. 4-Trends in government investments in environmental protection and government's overall investments in mainland Portugal, 1989-98.

De 1989 a 1993, os investimentos em ambiente evoluíram de 7,3 para 15,4 milhões de contos, a preços correntes, o que equivale a uma situação de manutenção do esforço de investimento. Face ao crescimento dos investimentos do Capítulo 50 do OE neste período, num total da ordem dos 1.264,6 milhões de contos, gastaram-se 64 milhões de contos na gestão e protecção ambiental, o que equivale a 5,1\% do total do Capítulo 50 do OE. Após 1994, é muito evidente o volume crescente de investimento induzido pelo Estado português (Capítulo 50 do $\mathrm{OE})$ em diversos domínios ambientais.

Pode ainda dizer-se que de 1994 a 1998, através do Capítulo 50 do OE, se efectua um total aproximado de investimentos públicos ambientais de 156,5 milhões de contos, num universo global de 2.280,5 milhões de contos investidos 
no desenvolvimento do país. Por outras palavras, neste último período, os gastos médios em ambiente aumentaram para 6,9\% do total do Capítulo 50 do OE, sugerindo o aumento assinalável do esforço financeiro exclusivo do Estado, naturalmente como complemento nacional ao estímulo dos fundos estruturais e de coesão. Resta ainda esclarecer que o decréscimo de investimento do Capítulo 50 do OE-total observado em 1995 fica a dever-se a uma maior fatia das «Outras Fontes» e das «Fontes Comunitárias» na composição do PIDDAC (DPP, 1995), que não foram consideradas na elaboração da figura 4.

Numa análise detalhada do Capítulo 50 do OE orientada para o ambiente, efectuada projecto a projecto, de 1989 a 1998, é possível detectar diferenças no tipo de investimentos no litoral do país e no interior, podendo mesmo propor-se uma tipologia ou faseamento de investimentos ambientais. O ciclo de financiamentos inicia-se com a predominância de projectos ligados à hidráulica, sobretudo agrícola, depois segue-se um ciclo ligado às infra-estruturas de abastecimento público de água e saneamento em áreas urbanas e, por último, os investimentos dirigem-se mais intensivamente à protecção do património natural, acompanhados, porém, da continuação dos trabalhos na área de saneamento básico e distribuição de água potável.

No Litoral, as obras de defesa da costa e a recuperação de áreas balneares, com o objectivo do cumprimento de normas de qualidade da água, são uma

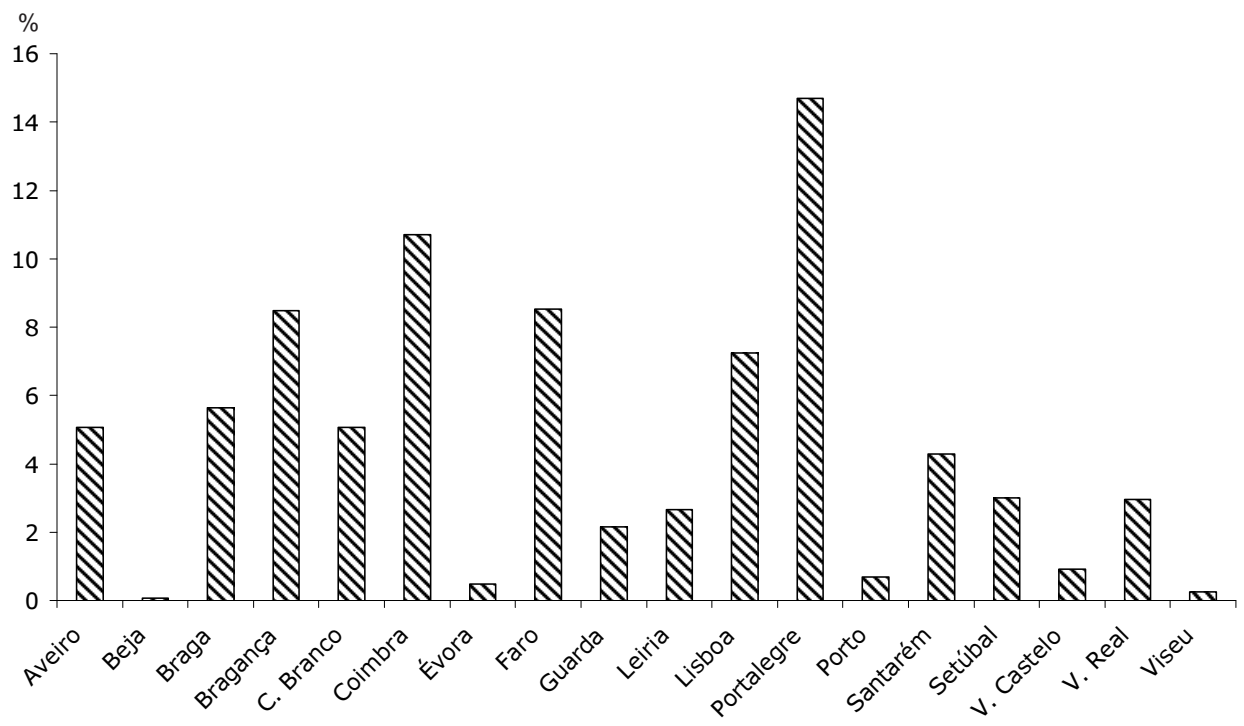

DPP, Regionalização do PIDDAC, 1989 a 1993 (com tratamento próprio)

Fig. 5 - Peso do Cap. 50 OE-Ambiente no Cap. 50 OE-total por distrito, 1989-93.

Fig. 5 - Trends in government investments in environmental protection as compared with the government overall investments by spatial units, 1989-93. 
tónica permanente ao longo do período considerado (acentuando-se a partir do II QCA), acompanhadas de iniciativas de reajustamento das redes públicas de abastecimento de água e de águas residuais. A tipologia de projectos encontrada no Litoral resulta destas áreas e suas envolventes serem alvo de pressão demográfica e concentração de actividades económicas.

Repartidas pelos períodos de 1989-93 e 1994-98, as figuras 5 e 6 referem-se à parcela do Capítulo 50 do $\mathrm{OE}$ destinada a investimento em programas/projectos ambientais por distritos e a figura 7 traduz a execução financeira do Capítulo 50 do OE - Ambiente que é possível assinalar ao nível do distrito, ponderada pela população residente.

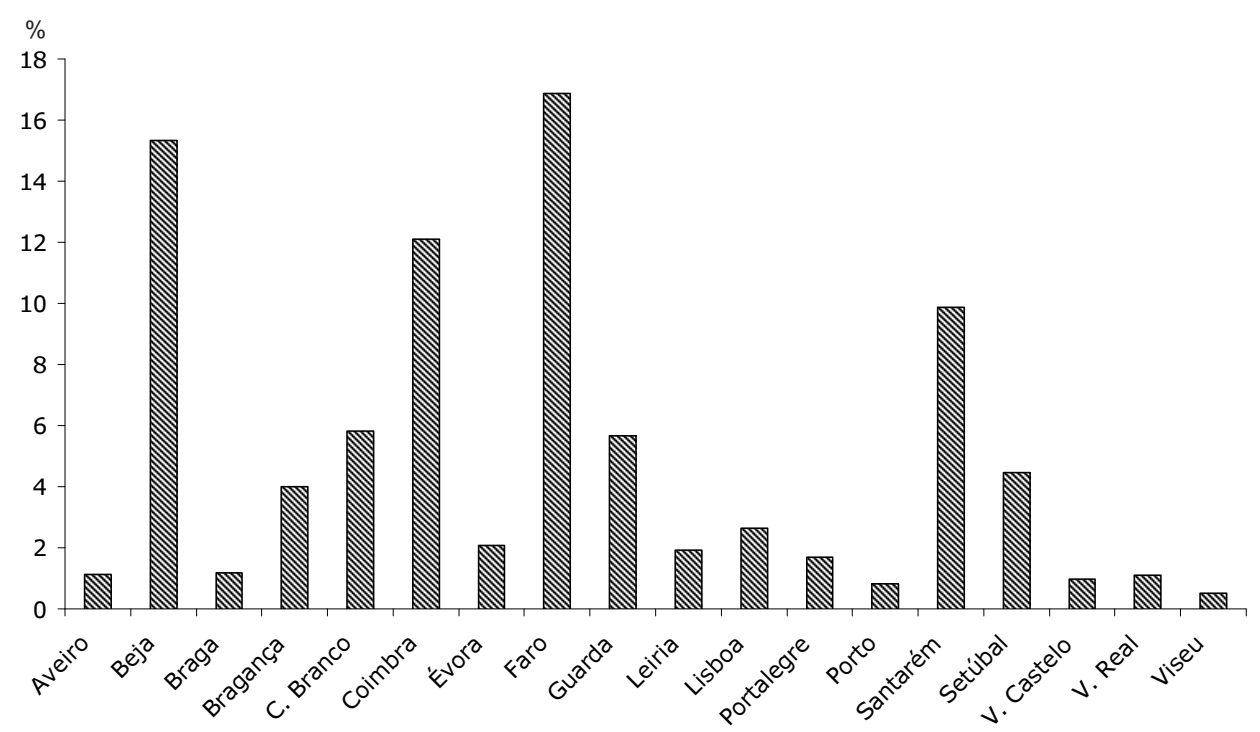

DPP, Regionalização do PIDDAC, 1994 a 1998 (com tratamento próprio)

Fig. 6 - Peso do Cap. 50 OE-ambiente no Cap. 50 OE-total por distrito, 1994-98.

Fig. 6 -Trends in government investments in environmental protection as compared with the government overall investments by spatial units, 1994-98.

Sendo a base desta informação os relatórios Regionalização do PIDDAC (Dpp, 1989 a 1998), dificilmente a interpretação dos valores expressos nas figuras traduzirá toda a realidade já que, segundo o DPP, apenas entre 40 a $60 \%$ do PIDDAC é espacializável; contudo, uma aproximação é possível. Alerta-se também, para o facto da distribuição espacial das acções ambientalmente relevantes não terem necessariamente uma relação com as fronteiras segundo as quais as autoridades legais e políticas actuam. Com efeito, muitos dos projectos definidos ao nível da política pública de ambiente têm uma localização difusa e 
alguns não apresentam uma matriz territorial, sobretudo aqueles que ocorrem ao nível da educação ambiental ou que decorrem do funcionamento de órgãos nacionais independentes de natureza consultiva, como por exemplo, o Conselho Nacional do Ambiente e do Desenvolvimento Sustentável (CNADS).

De acordo com as figuras 5, 6 e 7, no período de 1989 a 1993, verifica-se que os distritos cujo investimento em ambiente foi superior a $8 \%$ do seu Capítulo 50 do OE-total são Portalegre, Coimbra, Bragança e Faro. Os projectos de grande dimensão são típicos do interior, pois drenam a maior fatia de investimento ambiental - os aproveitamentos hidráulicos do Alto do Sabor e Marvão/Apartadura são, respectivamente, alguns dos projectos dos distritos de Bragança e Portalegre que justificam a relevância do investimento ambiental; o aproveitamento hidráulico do Baixo Mondego explica o investimento encontrado no

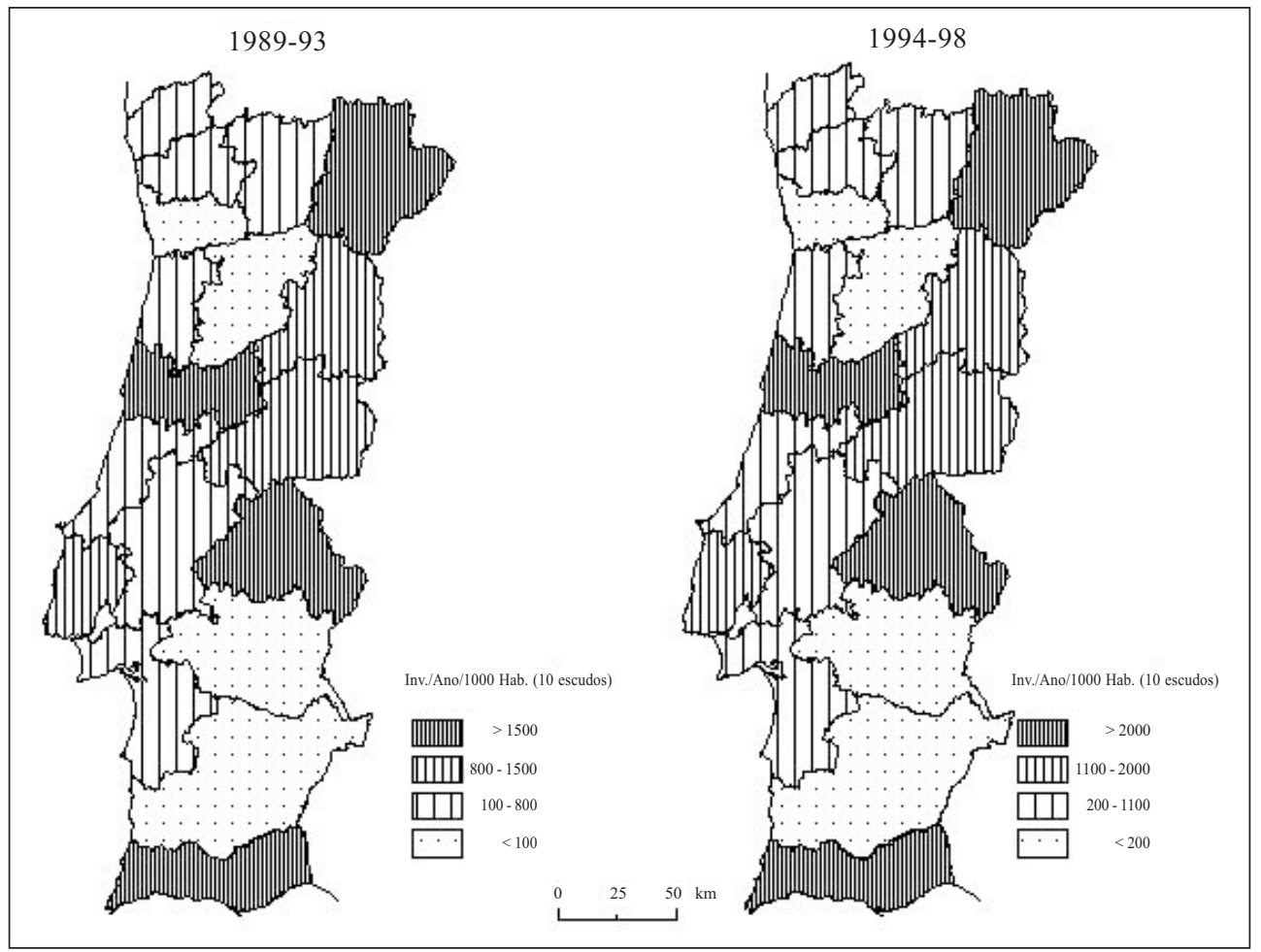

Fonte: DCP/MPART, 1989 a 1998

DPP, Regionalização do PIDDAC, 1989 a 1998 (com tratamento próprio)

Fig. 7 - Afectação distrital do Cap. 50 OE-Ambiente, 1989-98.

Fig. 7-Government investment in environmental protection by spatial units (inv./year/1000 inhab.), 1989-98. 
distrito de Coimbra. Naturalmente, são as preocupações relativas ao saneamento básico, ao abastecimento de água ao Algarve e os investimentos na reserva natural dos Sapais de Castro Marim e Vila Real de Santo António que justificam os amplos investimentos públicos no distrito de Faro. O investimento ambiental menos significativo detectado neste período ocorre nos distritos de Beja, Évora, Viseu e Porto, sendo em qualquer dos casos inferior a 2\% do Capítulo 50 do OE-total (em concreto, corresponde a gastos inferiores a 100 contos/ /ano/1000 habitantes).

Já no período 1994-98, o investimento ambiental aumenta significativamente em todo o país (não se registando distritos onde os gastos ambientais fossem inferiores a 100 contos/ano/1000 habitantes), tendo sido em algumas situações superior a $12 \%$ do Capítulo 50 do OE-total. É o caso dos distritos de Faro, Coimbra e Beja. Neste último distrito, o aproveitamento hidráulico do Enxoé e o Empreendimento de Fins Múltiplos do Alqueva (EFMA) absorvem grande parte do investimento. Santarém é um distrito que também se destaca neste período - despoluição da bacia do Alviela. No distrito de Castelo Branco evidenciam-se os investimentos no aproveitamento hidráulico da Cova da Beira e no distrito da Guarda o Parque Natural da Serra da Estrela absorve os maiores investimentos.

O investimento ambiental contempla igualmente programas de cooperação autárquica, por vezes multiregional. Pela sua preponderância, os projectos ambientais evidentes no Capítulo 50 do OE são sobretudo de dois tipos: grandes aproveitamentos hídricos (obras de regularização de leitos de cheia, irrigação agrícola, abastecimento público de água potável às populações, saneamento básico e armazenamento de água) e a valorização e gestão de áreas protegidas (protecção de espécies animais e vegetais e desenvolvimento económico e social das populações que ali residem).

Visto que as unidades de planeamento e ordenamento ambiental não se encaixam propriamente no modelo administrativo em vigor, muitas sinergias são criadas ao nível intermunicipal, face à necessidade de obtenção de economias de escala para efectuar despesas ambientais. Por último, muitos dos financiamentos estão dispersos pelo território nacional, implicando por isso elevados montantes, o que demonstra que os domínios do ambiente implicam, frequentemente, uma acção de âmbito supra-local/regional.

\section{A contribuição da administração local na gestão e protecção do ambiente}

A figura 8 reflecte o conjunto de iniciativas da administração local no que respeita às temáticas ambientais da sua responsabilidade. Sem dúvida que os domínios da água e resíduos são os que absorvem a maior fatia do financiamento. A evolução das despesas no serviço público de abastecimento de água é uma preocupação maior da administração local. O sector dos resíduos denota um crescimento regular e acentuado, de tal modo que, já no final da década, os montantes se aproximam dos gastos tidos com a água. Nos restantes domínios 


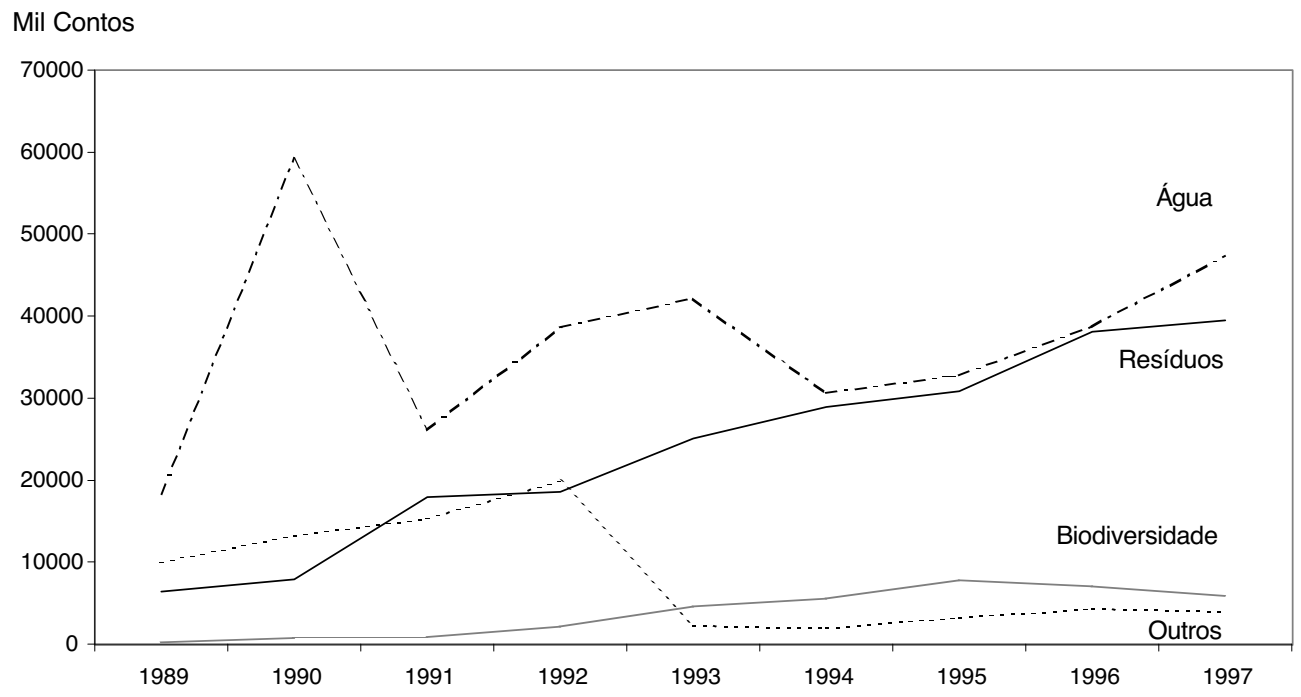

INE, Estatísticas do Ambiente, 1989 a 1997

Fig. 8 - Despesas dos municípios nos domínios de gestão e protecção ambiental, 1989-97 (os domínios I\&D, radiação, ruído e solos, não foram representados devido à sua incipiente expressão financeira).

Fig. 8-Local government environmental protection expenditure, 1989-97 (the environmental domains $R \& D$, radiation, noise and soils and groundwater are insignificant).

ambientais, os municípios assumem um investimento pouco relevante ${ }^{13}$, à excepção do domínio da biodiversidade, que em 1989 era quase nulo e, pouco a pouco, tem vindo a revelar-se uma preocupação crescente ao nível da intervenção municipal.

Estas observações reflectem o envolvimento efectivo e acção preponderante das autarquias nos domínios ambientais da sua competência e verifica-se que a década de 90 fica marcada pela actuação municipal no domínio dos resíduos. Com efeito, as despesas municipais em resíduos no Continente cresceram de 18,3\% para 40,8\% das despesas totais em ambiente entre 1989 e 1997 (INE, 1989 a 1997). Por último, a biodiversidade, um tema tradicionalmente associado à intervenção da administração central, surge a partir de meados dos anos 90 como uma preocupação na política ambiental da administração local.

Em termos regionais, a estrutura da repartição das despesas ambientais é semelhante: os domínios água e resíduos são aqueles em que os municípios

13 A evolução das despesas na categoria «outros» decorre, certamente, de um melhor conhecimento e clarificação estatística das despesas efectuadas pelos municípios em ambiente. 
aplicam a maioria das despesas em ambiente, enquanto a qualidade do ar, a protecção contra o ruído e as radiações e as actividades de I\&D em gestão e protecção ambiental ficam em último plano (Estatísticas do Ambiente, 1989-97). Como observado, as despesas em protecção da diversidade biológica e da paisagem são ainda modestas; contudo, o seu crescimento é revelador da emergência, na actualidade, de novas prioridades no desenvolvimento de políticas e programas para a agenda ambiental local.

\section{TRINTA ANOS DE POLÍTICA PÚBLICA DE AMBIENTE: UMA SÍNTESE}

A análise das estratégias do Estado português revela que, há cerca de trinta anos, a política nacional que então se perspectivou para o ambiente enquadrava-se no conjunto dos grandes projectos públicos, sob a orientação da política económica, e, portanto, revelava-se quase exclusivamente através de investimentos orientados para os aproveitamentos hidráulicos de ampliação de sistemas de drenagem agrícola, de abastecimento industrial e urbano, bem como de produção de energia hidroeléctrica e controlo de cheias. A procura da solução técnica mais adequada para o problema da carência de água concentrou, desde sempre, grande parte do esforço público nacional em ambiente. Com os consumos em crescimento e num panorama geral de disponibilidades desequilibrado, foram promovidas obras públicas de retenção e transferência de reservas hídricas.

De uma forma concisa, pode afirmar-se que desde a década de 70, o ambiente se associou a uma questão mais técnica do que científica, a base regulamentadora nacional tardou em estabelecer-se, assim como uma política de desenvolvimento regional com íntimas relações com o ambiente e o ordenamento.

Na década seguinte, é através do saneamento básico e da protecção da saúde pública que o ordenamento é associado, já numa óptica integrada, ao ambiente. Porém, essa associação foi tão breve quanto o Ministério da Qualidade de Vida. As obras hidráulicas continuariam a absorver grande parte dos recursos do Estado para o ambiente. Mas, é já em finais dos anos 80 que o Estado afirma a sua política, através da institucionalização de um acervo legislativo, continuada e sistematicamente, em substituição da publicação esporádica de leis. Será em 1987, com a publicação da Lei de Bases do Ambiente e da Lei das Associações de Defesa do Ambiente, que uma tal política é reconhecida institucionalmente e se integra no elenco governativo. Com estes actos legislativos montam-se os alicerces da política de ambiente: as preocupações conceptuais e o aumento da capacidade de intervenção da sociedade civil. Este foi, claramente, um período de transição, em que se assistiu à aceleração da concepção dos instrumentos político-jurídicos e ao estímulo da sociedade portuguesa na participação nas decisões e acções ambientais. 
Nos finais do século xx (década de 90) realizam-se algumas reformas institucionais tendo em vista o reordenamento de responsabilidades e o estabelecimento de uma política de ambiente coordenada e, neste contexto, é criado o Ministério do Ambiente e respectivas Direcções Regionais de Ambiente. É também o período em que se concebem estruturas que permitem estabelecer parcerias público-privadas para a gestão ambiental ${ }^{14}$. Com elas, o Estado assume um duplo papel de intervenção: assegurar a equidade de critérios e salvaguardar os interesses do planeamento à escala nacional e a procura de uma eficiente actuação ao nível local que defenda o interesse colectivo. Porém, estas medidas não seriam as únicas. A introdução do conceito de desenvolvimento sustentável na revisão constitucional e a criação do CNADS em 1997 foram das medidas institucionais mais emblemáticas da política de ambiente. No entanto, a afirmação dos princípios do desenvolvimento sustentável já havia sido esboçada com a publicação das duas leis referidas; apenas seriam institucionalizadas dez anos mais tarde em virtude das orientações de política da UE e respectivo aumento dos financiamentos, associados aos princípios da coesão económica e social.

Se bem que através dos Quadros Comunitários de Apoio foi possível dinamizar o investimento público nacional, por forma a construir plataformas em favor da preservação do ambiente e dos interesses da população, o processo de infra-estruturação está ainda longe de se encontrar encerrado e a viabilidade financeira de muitos dos empreendimentos ainda não está assegurada. A continuidade das obras e a captação do sector privado para os sistemas de saneamento e de abastecimento de água, com o duplo objectivo de melhorar a sua qualidade para consumo humano e o ordenamento dos usos dos recursos hídricos, são acções absolutamente indispensáveis para a harmonização do crescimento sectorial e regional. Por conseguinte, apesar da importância estratégica que o sector da água assume face às necessidades actuais e futuras do país, as despesas e investimentos noutros domínios ambientais na década de 90, nomeadamente na protecção da paisagem e biodiversidade e, sobretudo, na gestão dos resíduos, ilustram orientações de política - sectorial - renovadas.

Pode ainda afirmar-se que é apenas no último decénio do século xx que a gestão do Litoral se torna uma preocupação evidente nos programas de intervenção pública. Talvez como uma resposta tardia à degradação das áreas costeiras, que se tornou visível desde a implantação do regime democrático, devido à acelerada urbanização e industrialização em locais sensíveis do ponto de vista ecológico, após o que foi preciso investir na fixação da costa e na protecção marítima. E estas circunstâncias são as grandes responsáveis pela proliferação de investimentos em obras de reparação e ordenamento em quase todo o Litoral. Tal como a orla costeira e a rede nacional de áreas protegidas assumiram preponderância na estratégia ambiental do governo na década de 90, também assim aconteceu com o domínio dos resíduos.

14 Para desenvolvimento deste assunto, cf. QueIRós (2001, cap. 5). 
Conclui-se que a envolvente institucional deu importantes contributos na convergência em relação aos outros países da UE. Estabelecida a acção para a protecção e gestão da paisagem, estando o esforço de infra-estruturação em fase avançada, a política ambiental dos anos 90 permitiu esbater certos problemas ambientais e experiências positivas atestam a capacidade e vontade nacional para melhorar o ambiente. Deram-se então os primeiros passos de uma longa trajectória que ainda está por percorrer até ao desenvolvimento sustentável.

\section{AGRADECIMENTOS}

A autora agradece aos dois referees as suas críticas e comentários, que permitiram melhorar a qualidade do artigo. As opiniões expressas são, no entanto, da exclusiva responsabilidade da autora.

\section{BIBLIOGRAFIA}

Antas, A. (1987) - Gestão de resíduos em Portugal. Deitar fora é gastar o futuro. MPAT/ MARN-DGQA, Lisboa: 2-5.

Correia da Cunha, J. (1999) - Das origens da política de ambiente em Portugal. Associação de Telecentros Rurais de Portugal, 3 vol., Lisboa.

Correia da CUnHA, J. (2000) - Núcleo de Estudos de Problemas da Água. Um pequeno passo para a mudança que se impunha na gestão dos recursos hídricos, Lisboa (polic.).

Correia, F. N. (1995) - Ambiente e Desenvolvimento na Região de Lisboa e Vale do Tejo. Inforgeo, 9/10, Lisboa:11-18.

Daveau, S. (1991) - Comentários e Actualização. In O. Ribeiro e H. Lautensach Geografia de Portugal. IV. A Vida Económica e Social. Edições Sá da Costa, Lisboa:1035-1111 e 1193-1228.

DGA (1994) - Relatório do Estado do Ambiente 1994. MARN/DGA, Lisboa.

DgQA (1990) - Anuário da Qualidade do Ambiente 1989/90. MARN/SEADC/DGQA, Lisboa.

DPP (1989 a 1998) - Regionalização do PIDDAC. MPAT/SEDR/Departamento de Prospectiva e Planeamento, Lisboa.

DPP (1995) - Relatório de Execução. MEPAT/SEDR/Departamento de Prospectiva e Planeamento, Lisboa.

DpP (1996) - Relatório de Execução. MEPAT/SEDR/Departamento de Prospectiva e Planeamento, Lisboa.

DPP (1998) - Relatório de Execução. MEPAT/SEDR/Departamento de Prospectiva e Planeamento, Lisboa.

Eurostat (1999) - Environmental Protection Expenditure by the EU Institutions, Data 1994-99. Eurostat, Luxemburgo. 
Evangelista, J. (1992) - Razão e Porvir da Educação Ambiental. Instituto Nacional do Ambiente, Lisboa.

INE (1989 a 1997) - Estatísticas do Ambiente. Instituto Nacional de Estatística, Lisboa.

Ipamb (1999) - A Educação Ambiental na Política Pública de Ambiente. Um historial e uma bibliografia de referência. Instituto de Promoção Ambiental, Lisboa.

MA/SgDrh (1998) - Anuário 98. Ministério do Ambiente/Secretaria Geral - Direcção de Recursos Humanos, Lisboa.

MARn (1994) - Plano Nacional da Política de Ambiente (versão preliminar para discussão pública). Ministério do Ambiente e dos Recursos Naturais, Lisboa.

Melo, J. J.; Pimenta, C. (1993) - Ecologia e Ambiente. Col. O que é, Difusão Cultural, Lisboa.

PresidênCia do Conselho (1974) - IV Plano de Fomento 1974-79. Imprensa Nacional-Casa da Moeda, Lisboa.

QueIrós, M. (2001) - O Desafio Ambiental, as Políticas e a Participação dos Actores. Dissertação de Doutoramento em Geografia Humana, Universidade de Lisboa, Lisboa (polic.).

Ribeiro telles, G. (1995) - A propósito do início da política de ambiente em Portugal. Revista das Autarquias, 2: 73-80.

Silva Lopes, J. (1996) - A economia Portuguesa desde 1960: panorama geral da evolução económica entre 1960 e o início da década de 90. A Situação Social em Portugal, 1960-1995, Lisboa: 233-246.

Simões, J. M. (1985) - Desenvolvimento e gestão das Infra-estruturas na Área Metropolitana de Lisboa. Redes Colectivas de Saneamento Básico e Electrificação. E.P.R.U., 23, CEG/UL, Lisboa.

Soromenho-Marques, V. (1994) - Regressar à Terra. Consciência Ecológica e Política de Ambiente. Fim de Século, Lisboa.

Soromenho-Marques, V. (1998) - O Futuro Frágil. Os desafios da crise global do Ambiente. Publicações Europa-América, Lisboa.

Veiga da Cunha, L.; Lino Correia, M.; Gonçalves, A. S.; Figueiredo, V. A. (1974) - Fundamentos de uma nova política de gestão das águas em Portugal. MESA/SEOP/DGSH, Lisboa. 